\title{
Living with pain: the experience of children and adolescents in palliative care*
}

\author{
VIVENCIANDO A DOR: A EXPERIÊNCIA DE CRIANÇAS E ADOLESCENTES EM \\ CUIDADOS PALIATIVOS
}

\section{VIVIR CON DOLOR: LA EXPERIENCIA DE LOS NIÑOS Y ADOLESCENTES EN LOS CUIDADOS PALIATIVOS}

\section{Camila Amaral Borghi' ${ }^{1}$, Lisabelle Mariano Rossato², Elaine Buchhorn Cintra Damião², Danila Maria Batista Guedes ${ }^{3}$, Ellen Maria Reimberg da Silva ${ }^{3}$, Silvia Maria de Macedo Barbosa ${ }^{4}$ Rita Tiziana Polastrini ${ }^{5}$}

\begin{abstract}
A qualitative study was conducted with semi-structured interviews with the aim of understanding the experience of children and adolescents under palliative care when managing pain daily and how they describe the intensity, quality and location of pain. We used Piaget's theory of cognitive development as a theoretical framework and oral history as a methodological framework. We found four themes: describing pain; seeking a life closer to normality, despite pain and disease; using a variety of alternatives for pain control; and living with damaged physical appearance. Although pain is a limiting factor in the lives of children and adolescents, we found that they faced their daily pain and still had a life beyond pain and illness. In addition, we highlight the relevance of nurses' understanding that effective management of pain in children is essential for a normal life and less suffering.
\end{abstract}

\begin{abstract}
RESUMO
Objetivo: Conhecer como as crianças e adolescentes em cuidados paliativos manejam a dor em seu cotidiano e como a descrevem em intensidade e qualidade. Método: Pesquisa qualitativa realizada com entrevistas semiestruturadas com seis crianças entre sete e 17 anos. A teoria do desenvolvimento cognitivo de Piaget foi utilizada como marco teórico e a história oral como referencial metodológico. Resultados: Foram encontrados quatro temas: Descrevendo a dor; Buscando uma vida mais próxima da normalidade, apesar da dor e da doença; Utilizando várias alternativas para o controle da dor; e Vivenciando a autoimagem prejudicada. Conclusão: Apesar de a dor ser um agente limitante na vida de crianças e adolescentes, constatamos que enfrentavam a dor diariamente e, mesmo assim, tinham vida além da dor e da doença. Acrescentamos, ainda, a importância de os enfermeiros compreenderem que o manejo eficaz da dor é essencial para uma vida mais próxima da normalidade, reduzindo seu sofrimento.
\end{abstract}

\author{
DESCRITORES \\ Criança \\ Adolescente \\ Manejo da dor \\ Cuidados paliativos \\ Autoimagem \\ Enfermagem pediátrica
}

\begin{abstract}
RESUMEN
El estudio tuvo como objetivo conocer la experiencia de niños y adolescentes en cuidados paliativos en el manejo diario del dolor. La investigación cualitativa fue realizada con entrevistas semi-estructuradas con seis niños entre siete y 17 años. La teoría del Desarrollo cognitivo de Piaget fue utilizada como Marco teórico y la Historia Oral como Referencial Metodológico. Cuatro temas fueron encontrados: describiendo el dolor; buscando una vida más próxima de la normalidad, a pesar del dolor y la enfermedad; utilizando varias alternativas para el control del dolor y viviendo la autoimagen perjudicada. A pesar del dolor ser un agente limitante en la vida de los niños y adolescentes, verificamos que enfrentaban el dolor diariamente y, que así mismo, tenían vida además del dolor y la enfermedad. Adicionamos, aun, la importancia de los enfermeros comprender que el eficaz manejo del dolor es esencial para una vida mas próxima de la normalidad, reduciendo su sufrimiento.
\end{abstract}

*Extracted from the dissertation "Convivendo com a dor: a perspectiva da criança e do adolescente em cuidados paliativos", School of Nursing, University of São Paulo, 2012. ${ }^{1}$ Master in Health Sciences, School of Nursing, University of São Paulo, São Paulo, SP, Brazil. ${ }^{2}$ Doctor Professor, Doctor Professor, Department of Mother-Childhood and Psychiatric Nursing, School of Nursing, University of São Paulo, São Paulo, SP, Brazil. ${ }^{3}$ Student of the Master's program in Health Sciences, School of Nursing, University of São Paulo, São Paulo, SP, Brazil. ${ }^{4}$ Technical Director of Health Service, Child Institute, Clinic Hospital, Medicine College, University of São Paulo, São Paulo, SP, Brazil. ${ }^{5}$ Nurse specialized in Administration of Health Services-Hospital Administration, Public Health College, University of São Paulo, São Paulo, SP, Brazil. 


\section{INTRODUCTION}

Pain is a stressful event for children and adolescents and may have negative physiological, psychological and behavioral consequences. It is even more serious when combined with chronic disease. Pediatric palliative care is a care philosophy that must be applied from the moment chronic disease is diagnosed until it stops responding to curative interventions. Thereafter, the focus of care shifts to the improvement of quality of life for children, adolescents and their families, aiming to decrease suffering and pain ${ }^{(1-3)}$.

Pediatric palliative care must also be considered for diseases that evolve chronically, affect one or more systems and require specialized care. We emphasize that such care must also be applied after the first year of the course of the disease, even in those cases where the disease is not in its terminal phase. Some children with chronic disease may require palliative care from birth through adulthood because of the chronic and prolonged evolution of the disease. However, we can find in our area a frequent association among palliative care, terminality and oncologic diseases, among both health professionals and children's families ${ }^{(4-6)}$.

Many children and adolescents with chronic diseases and/or in the end-of-life phase live with pain daily, in addition to other signs and symptoms, such as: fatigue, dyspnea, anorexia, nausea, vomiting, insomnia, anxiety, despair, frustration and impotence when managing daily situations $^{(7-9)}$.

Considering the increase in the frequency of chronic diseases in all age groups, it is necessary for nurses and other health professionals to understand through their own accounts the experiences of children and adolescents who are suffering from pain and are receiving palliative care, making it possible to act adequately in the evaluation, management and relief of pain ${ }^{(10-17)}$.

Although there are publications concerning the quality of life of children in pain under palliative care and their families, there is a scarcity of studies that analyze the experience from the perspective of children and adolescents under palliative care regarding the management of pain in their daily lives ${ }^{(13-17)}$.

Therefore, we chose to develop a qualitative and exploratory study with the objective of understanding how children and adolescents under palliative care manage pain in their daily lives and how they describe its intensity and quality.

\section{METHOD}

We chose to develop a qualitative study, considering the unique character of the experience of managing pain in children and adolescents under palliative care.

To meet the proposed objectives, we used the thematic oral history methodological strategy, whose premise is the perception of the past as something that continues into the present, this approach also seeks the interviewee's clarification or opinion regarding a specific subject or preestablished theme. In oral history, the deponent is considered a contributor, which results in an affinity relationship between interviewer and interviewee ${ }^{(18-19)}$.

The study was approved by the Research Ethics Committee of the College of Nursing, University of São Paulo, process no. 1060/2011, meeting the requirements of Resolution no. 196/96 of the National Health Council (Conselho Nacional de Saúde). It was conducted in the palliative care and pain clinic of a pediatric teaching hospital, of public character and third level, from December 2011 through June 2012.

The research collaborators were children and adolescents in the age group from 6 through 17 years, 11 months and 29 days who agreed to participate in the interview; the children were accompanied by a responsible adult. All of them had chronic diseases, with no possibility of cure, and were under palliative care and receiving pain treatment.

We chose this age group because school children and adolescents can give clear accounts more easily than younger children ${ }^{(20)}$.

The option to choose childhood character code names and nicknames was offered to the collaborators as a way to guarantee privacy and anonymity regarding their identities. The code names, ages, and diseases were as follows: Barney, age 6, epidermolysis bullosa; Valéria, age 6; epidermolysis bullosa; Jay, age 13, epidermolysis bullosa; Pucca, age 13 osteogenesis imperfecta; Sininho, age 17, xeroderma pigmentosum; and Dica, age 17, human T-cell lymphotropic virus (HTLV)/hereditary spastic paraparesis.

Initially, selection of the children and adolescents began with a meeting with the palliative care and pain clinic team, who suggested likely collaborators. After that, we got in touch with some of the adults responsible for the children and adolescents in the clinic itself, explaining the research. With consent from the responsible adults, meeting were scheduled with the children and adolescents on the day of their appointments at the clinic at different times.

The semi-structured interview was conducted using some guiding questions:

Can you tell me how your daily life is at home? Who helps you? Can you tell me how your daily life is at school? Who helps you? Can you tell me how your pain is ? Can you tell me when you feel the most pain? Can you tell me what you do to alleviate your pain? Who helps you?

The interviews were digitally recorded and were processed in three stages, according to the methodology: 1. Transcription: transcription of the interview including errors, repetitions and speech intonation, as well as the interviewer questions; 2. Textualization: incorporation of the questions in the collaborator's answers. The text
Living with pain: the experience of children and adolescents in palliative care

Borghi CA, Rossato LM, Damião DBC, Guedes DMB, Silva EMR, Barbosa SMM, Polastrini RT 
becomes more fluid, in singular first person, exclusively from the collaborator, who is seen as a unique character. The text is reorganized based on chronological/thematic indications, bringing together the themes that were addressed and resumed at different times. In this stage, we choose the vital tone (a phrase to be placed at the introduction of the collaborator's story because it summarizes the narrative); 3 . Transcreation: a stage in which the text is completely recreated, perhaps being reworked many times, respecting directions agreed upon with the collaborator, where elements from outside the text are incorporated. The mood of the interview is recreated, with the objective of bringing to the reader the interaction that occurred between interviewer and collaborator ${ }^{(18-19)}$.

When the last stage is finished, the final version of the text is reached. The interview is only made available for viewing or publication after the adult responsible for the child or adolescent has checked the transcription and signed an assignment term for the use of the generated documents, recordings and transcriptions. The assignment term is a crucial document to ensure the legal status of the use of the interview. Therefore, after the methodological stages have been finished, the collaborator and the responsible adult approve the final text in order for it to be used in research ${ }^{(18-19)}$.

After reading all the accounts, we concluded that they had their own meanings, enabling the identification of certain patterns that constructed the focus of the history. This way, it was possible to identify the most significant aspects of the experience of managing pain for the children and adolescents. All of the accounts were registered throughout the histories and compared amongst themselves with the objective of identifying similarities among the histories, which made it possible to connect the six narratives.

As a theoretical reference, we used Piaget's theory of cognitive development (TCD), which enabled us to evaluate cognitive and behavioral aspects that explained the experience of managing pain for children and adolescents.

Piaget was the first to postulate how children's knowledge of the world changes with age ${ }^{(21)}$. He proposed three stages of cognitive development: intuitive, concrete operational and formal operational. According to this theory, children are capable of making logical deductions, naming and working with quantitative relations between things and concrete thoughts, when they enter the concrete logic thought stage, at around seven years of age. However, the capacity for abstract reasoning on any level is only acquired in adolescence ${ }^{(22-23)}$.

Each stage of development is built on the achievements of the previous stage and derived from it in a continuous and orderly process. Intellectual evolution is maturational and divided into four stages: 1 . Sensorimotor (from birth to two years), composed of six substages that are guided by the senses with which simple learning occurs. 2. Preoperational (from two to seven years of age), which has as its main characteristic egocentrism, which in this sense does not mean egoism but the incapacity to put oneself in the place of others. 3. Concrete Operational (from 7 to 11 years of age), in which thought becomes increasingly logical and coherent. The child is capable of classifying, specifying, sorting and organizing facts regarding the world to use in problem solving. New concepts of permanence and conservation develop, which means that the child understands that physical factors, such as volume, weight and number, remain the same even if external appearance changes. 4. Formal Operational (from 11 to 17 years of age), in which adolescents are capable of thinking in abstract terms and arriving at logical conclusions from a set of observations. In the same way, they can also elaborate and test hypotheses test them, as well as think about abstract, theoretical and philosophical ideas ${ }^{(21-23)}$.

\section{RESULTS}

The following themes emerged from the accounts of the children and adolescents, analyzed using Piaget's theory: describing pain, seeking a life that is closer to normality, despite pain and disease; using various alternatives for managing pain; and living with a damaged self-image.

Describing pain. Pain is considered a subjective experience and self-reporting instruments are considered the gold standard for evaluation. Language may be considered the main method of expressing pain. Starting at 18 months of age, children already have words to describe pain and may prefer to use the word bruise instead of pain. Children's cognitive development from three to four years of age is enough to allow reporting its intensity, in other words, much or little. Six-year-old children fall in the preoperational stage, like as Barney, who describe pain during the bandaging procedure as strong (evaluative dimension), and as a pain that hurts and pulls (sensory dimension).

We have to apply bandages, it hurts to apply bandages, that is why I take a shower and apply bandages every two days. It hurts when the bandage is removed, it is a pain that hurts, it is a pain that pulls, it makes me cry and it is tiring. If I had to rate pain, from zero to ten, I would say that my pain is a 10 !

Children of nine years of age, such as Valéria, are in the concrete operational stage, when thought becomes increasingly logical and coherent. Children in this stage are capable of classifying, specifying, sorting and organizing facts regarding the world to use in the resolution of problems. They also understand that physical factors, such as volume, weight and number, persist, even if external appearance changes.

Hence, Valéria describes her pain experiences as strong (evaluative dimension), stabbing and prickling pain (sensory dimension) and as a pain that makes her feel annoyed (miscellaneous). The pain dimensions that Valéria reports are result of thigh and arm lesions, and she men- 
tions feeling pain more intensely in the afternoon because she spends a long time sitting at school.

I feel a little pain, sometimes, in my wound. I have a wound on my thigh; it is the one that hurts the most. It is a stabbing pain. If I could rate the pain from zero to 10 , it would be 10 ! Sometimes, in addition to the pain in my thigh, I feel a little stab on my arm! It is a prickling pain, annoying and strong.

The teenagers Jay, Pucca, Sininho and Dica, used a wider and more abstract way of thinking; they could describe their pain in all dimensions, such as: strong pain (evaluative dimension), pressing pain (miscellaneous), warming pain, jerking pain that throbs, stabbing (sensory dimension) and heavy pain (affective dimension).

Jay describing the pain:

The pain is strong, sometimes, it is so varied, sometimes it comes pushing, sometimes it comes, like, prickling, then it comes warming, it comes moving my bones, sometimes I don't know what to do, it is really hard to explain...

Pucca frequently feels pain and described it thus:

When I go to school I feel pain because I sit for a long time, then my back hurts, a burning pain, and the legs, a strong pain thatjerks. If I had to rate the pain from zero to 10 , the back pain would be 4 and the leg pain would be between 6 and 7 .

Sininho develops tumors that need to be surgically removed. She reported her pain:

I recently had a tumor removed and the stitch that I had on my neck broke, then I felt pain, a lot of pain, a strong pain that throbbed! In addition to that, I have headaches, which makes me crazy.

Dica's reports her experience:

I feel pain in my legs every day, it is constant. It is a heavy pain, sometimes it burns, and when I wake up, my leg feels very heavy for me to get up, it is very hard. If I had to rate the pain's intensity from zero to 10 , I would rate it a 10 !

Seeking a life that is closer to normality, despite pain and disease. The daily life of the child and adolescent is severely affected by pain, causing much suffering, especially when pain management is ineffective. Nevertheless, five collaborators reported having a good relationship with their healthy friends at school, as in the following accounts:

I usually do my lessons... many lessons, there is physical education and I chat with my friends. My best friends are C., M.E., R. and M. We play pique perna and many games! My favorite is pique perna! (Valéria)

Then I go to school. My friends stop by my house and we go together, on foot, and I go in my chair. The friends who go with me are C., F., P., M., J., F., J. and H. (Pucca)

G., he is from school, he is in my class for the second time! He helps me a lot in class, gets my supplies for me when I am not able, when I am not able to write he writes with me.
He is important! (Jay)

The collaborators, in addition to living with healthy children and adolescents of the same age group, also relate to people who suffer the same condition, which enables an exchange of experiences.

I know other people who have this disease. There is $\mathrm{D}$., who has the same disease, E. and K., also. I met them at the hospital. E. also had a brother with this disease. (Sininho)

I know a lot of people here At my doctor's office who have epidermolysis, there is L., A., B., and D. But out of the hospital, I don't know no one else. (Jay)

This study's findings also show that the collaborators engaged in activities and even adapted to some sports, despite their physical limitations.

Barney, who was in the preoperational stage, preferred games that he could play alone, such as:

Sitting in the armchair and playing videogames is what I

like the most to do.

On the other hand, children in the concrete operational stage, such as Valéria, start to relate to children of the same age:

In school, I am in third grade, fourth year. I have many friends!

The cognitive development of adolescents is in constant evolution, presenting characteristics of adaptability and flexibility, which belong to the formal operational stage. In addition to that, they appreciate group activities.

Pucca, for example, because of her disease, needs to use a wheelchair to move around; however, she was able to adapt to sports, such as basketball and swimming. I like to play basketball in school because they let me practice! I used to go swimming also, I went to the Association for the Care of Special Needs Children (Associação de Assistência à Criança Deficiente), but I had to stop two months ago because I was breaking bones.

The adolescents also mention philosophical and abstract aspects, such as Sininho, when reporting her dream: Ahhh, I dream of being cured, but only if it is in the new world! Thereby, she recognizes that her disease is incurable; however, she waits for the cure, but not for herself.

Using many alternatives for managing pain. In order to manage pain effectively, it is necessary that treatment include pharmacological and nonpharmacological measures.

The children and adolescents use medication and nonpharmacological alternatives, such as massages, hydrotherapy, acupuncture and cryotherapy in the belief that these measures will alleviate their pain.

Barney, during his account, reports:

What I dislike the most is taking showers. I have to apply bandages, it hurts to apply bandages; and then he says:
Living with pain: the experience of children and adolescents in palliative care

Borghi CA, Rossato LM, Damião DBC, Guedes DMB, Silva EMR, Barbosa SMM, Polastrini RT 
In the shower, it stings to take off the bandages in order to get under the shower. When I am already under the shower, it does not hurt... So I like this part of the shower, because it does not hurt!

This is explained by the fact that children in the preoperational stage interpret events in terms of the use that they have for it; in other words, Barney considers the shower a time to feel pain, because he has to take off the bandages.

As children's reasoning in the preoperational stage does not go beyond the observable, they cannot make deductions or generalizations. The reasoning is also transductive -- one event may cause another. For Barney, the shower is an event that happens after the removal of the bandages, which causes pain; because of that, he does not like the shower. However, the shower also makes the pain go away; thus, he likes this part of the shower, but cannot recognize it as a nonpharmacological alternative for pain relief.

Valéria, who can employ inductive reasoning, can link pain relief to an event, recognizing the shower as a pain relief measure, when reporting that:

When I am in pain at home, when it is very painful, my mother showers me, and then it gets better!

Living with a damaged self-image. Some collaborators, in addition to suffering constantly with pain, need to manage their appearance, which is often damaged by the disease and, many times, they frequent hear comments from their colleagues that make them sad.

One day, a boy asked me if my fingers were glued because I had put glue on them. I was angry with this friend from school. (Barney)

Considering that the adolescents live in a constant search for approval from their group, when our collaborators hear these comments, they feel excluded, because, in general, they have the capacity to reach logical conclusions from a set of observations.

Once a boy called me hurt panther... it is a very hard situation, being 13 and having a disease like this. Because you see rejection from other people. Even for height, they make a lot of fun of you, they call me shorty, stumpy... Sometimes in other people's minds, I don't know what goes on, it is hard. (Jay)

\section{DISCUSSION}

Considering the perspective of children and adolescents in palliative care regarding daily management of pain, we can highlight the following relevant aspects.

The fact that the children and adolescents are capable of expressing the characteristics of their pain directly affects how the nurses must alleviate the child's pain ${ }^{(12)}$. Nurses must understand that children of primary school age communicate pain in concrete terms ${ }^{(24)}$, like Barney and Valéria. These children understand the concepts of order and sorting, and are generally able to describe in detail the intensity, location and quality of pain ${ }^{(24)}$.

It is important to note that the collaborators in the preoperational stage of development also did not use affective aspects to describe their pain, owing to their inability to reflect on nonobservable elements ${ }^{(25)}$. It is known that children in the concrete operational stage go through a cognitive progression in which event interpretation is based on what they perceive, because of inductive reasoning ${ }^{(16)}$.

As for adolescence, it is defined by adaptability and flexibility of reasoning ${ }^{(16)}$. During the formal operational period, cognitive structures reach their maximum qualitative potential with the development of propositional thought, in other words, to think about thinking. This phase is defined by a capacity for introspection and thinking about what is purely abstract, which, in terms of conceptualization of pain, includes physical and psychological components ${ }^{(26)}$.

Despite the fact that the literature notes that chronic pain in children and adolescents causes school truancy, inability take part in physical activities, sleep disturbances and problems relating to people in the same age group ${ }^{(7,9,27)}$, these aspects were not identified in this study. Analysis of the accounts showed that children and adolescents kept a social support network through their school friends, neighbors and family members, who helped them have a life that is closer to normality.

Agreeing with the literature, the collaborators in this research also understand that managing pain requires pharmacological and nonpharmacological actions ${ }^{(28-29)}$. The children have a tendency to interpret pain management in a concrete manner, only making evaluations such as good, bad, like or does not like. Adolescents, however, can understand and evaluate techniques for managing pain and understand cause and effect relationships, as well as the functions of pharmacological and nonpharmacological actions.

The question of self-image was identified as very relevant for all of the collaborators' age groups. It is known that adolescents in general worry about their physical appearance, spending a lot of their time and energy working on their appearance. In this sense, the adolescents' accounts evidenced the importance of self-image and the suffering caused by comments about their appearance. Even children notice and suffer from the questions and observations that the colleagues make about them. The literature mentions that school children are increasingly conscious of physical differences in relation to their peers. If these perceptions are accompanied by unpleasant comments or mockery, they can make the child feel inferior or undesirable ${ }^{(22,30)}$. 


\section{CONCLUSION}

We saw that pain could be a limiting agent in the life of children and adolescents. The collaborators managed pain daily and even then, they could go to school, live with other people, play and practice sports differently from what is described in the literature. They had lives beyond pain and disease, truly being children and adolescents.

Interviewing children and adolescents is challenging, because it is necessary to use an effective approach and develop a relationship based on mutual trust. We noticed that parents became uncomfortable when listening

\section{REFERENCES}

1. Cleve LV, Muñoz CE, Riggs ML, Bava L, Savedra M. Pain experience in children with advanced cancer. J Pediatr Oncol Nurs. 2012;29(1):28-36.

2. Academia Nacional de Cuidados Paliativos. Manual de cuidados paliativos. Rio de Janeiro: Diagraphic; 2010.

3. European Association of Palliative Care, Steering Committee. Taskforce: IMPaCCT: standards for paediatric palliative care in Europe. Eur J Palliat Care. 2007;14(3):109-14.

4. Jünger $S$, Vedder $A E$, Milde $S$, Fischbach $T$, Zernikow B, Radbruch L. Paediatric palliative home care by general paediatricians: a multimethod study on perceived barriers and incentives. BMC Palliat Care. 2010;9:11.

5. Jünger $S$, Pastrana T, Pestinger M, Kern M, Zernikow B, Radbrunch. Barriers and needs in Paediatric Palliative home care in Germany: a qualitative interview study with Professional experts. BMC Palliat Care. 2010;9:10.

6. Beyer JE, Simmons LE. Home treatment of pain for children and adolescents with sickle cell disease. Pain Manag Nurs. 2004;5(3):126-35.

7. Kashikar-Zuck S, Goldschneider KR, Powers SW, Vaught MH, Hershey AD. Depression and functional disability in chronic pediatric pain. Clin J Pain. 2001;17(4): 341-9.

8. Kashikar-Zuck S, Vaught MH, Goldschneider KR, Graham TB, Miller JC. Depression, coping, and functional disability in juvenile primary fibromyalgia syndrome. J Pain. 2002;3(5):412-9.

9. Tsao $\mathrm{JCl}$, Meldrum M, Kim SC, Zeltzer LK. Anxiety sensitivity and health-related quality of life in children with chronic pain. J Pain. 2007;8(10):814-23.

10. Ljungman G, Gordh T, Sörensen S, Kreuger A. Pain in pediatric oncology: interviews with children, adolescents and their parents. Acta Pediatr. 1999;88(6):623-30. to the accounts of their children, especially feelings and thoughts regarding pain and disease.

A limiting factor in our study was the low number of collaborators, as well as the fact that e two age groups were being analyzed simultaneously. Another relevant question was the absence of collaborators with better financial resources. It seems possible that families with better conditions can offer more treatment options for their children, which may change the experience of managing pain. We recommend that new studies be conducted to determine the socioeconomic-cultural influence on managing pain in children and adolescents under palliative care.

11. Kortesluoma RL, Nikkonen M. "You just have to make the pain go away"- children's experiences of pain management. Pain Manag Nurs. 2008;9(4):143-9.

12. Azize PM, Humphreys A, Cattani A. The impact of language on the expression and assessment of pain in children. Intensive Crit Care Nurs. 2011;27(5):235-43.

13. Kortesluoma RL, Nikkonen M. Hospitalized children drawing their pain: the contents and cognitive and emotional characteristics of pain drawings. J Child Health Care. 2008;12(4):284-300.

14. Kortesluoma RL, Nikkonen M. 'The most disgusting ever': children's pain descriptions and views of the purpose of pain. J Child Health Care. 2006;10(3):213-27.

15. Kortesluoma RL, Nikkonen M. "I had this horrible pain": the sources and causes of pain experiences in four to eleven year old hospitalized children. J Child Health Care. 2004;8(3):210-31.

16. Esteve R, Marquina-Aponte V. Children's pain perspectives. Child Care Health Dev. 2012;38(3):441-52.

17. Rossato LM, Magaldi FM. Multidimensional tools: application of pain quality cards in children. Rev Latino Am Enferm. 2006;14(5):702-7.

18. Meihy, JCSB. Manual de história oral. 5a ed. São Paulo: Loyola; 2005.

19. Meihy JCSB, Holanda F. História oral: como fazer, como pensar. 2a ed. São Paulo: Contexto; 2011.

20. Faux AS, Walsh M, Deatrick JA. Intensive interviewing with children and adolescent. West J Nurs Res. 1998;10(2):180-94.

21. Piaget J, Inhelder B. Memory and Intelligence. New York: Basic Books; 1973.

22. Hockenberry MJ, Wilson D. Wong: fundamentos de enfermagem pediátrica. 8a ed. Rio de Janeiro: Elsevier; 2011. 
23. Bee H, Boyd D. A criança em desenvolvimento. $12^{\text {a }}$ ed. Porto Alegre: Artmed; 2011.

24. Franck LS, Greenberg CS, Stevens B. Pain assessment in infants and children. Pediatr Clin North Am. 2000;47(3):487-512.

25. Wilden S, Russel J. Children acquire emotion categories gradually. Cogn Dev. 2008; 23(2):291-312.

26. Gaffney A, Dunne E. Developmental aspects of children's definitions of pain. Pain. 1986;26(1):105-17.

27. Chalkiadis GA. Management of chronic pain in children. Med J Aust. 2001;175(9): 464-79.
28. Srouji R, Ratnaplan S, Schneeweiss S. Pain in children: assessment and nonpharmacological management. Int J Pediatr [Internet]. 2010 [cited 2014 Mar 15]. Available from: http://www.ncbi.nlm.nih.gov/pmc/articles/PMC2913812/

29. Silva EA, Corrêa Neto JL, Figueiredo MC, Branco AB. Práticas e condutas que aliviam a dor e o sofrimento em crianças hospitalizadas. Comun Ciênc Saúde. 2007;18(2):157-66.

30. Dures E, Morris M, Gleeson K, Rumsey N. The psychosocial impact of epidermolysis bullosa. Qual Health Res. 2011;21(6):771-82. 